\title{
BOOKS RF(TIVED)
}

\section{Computer science}

CRONHJORT, B. (ed.) Real Time Programming 1978. Proceedings of the IFAC/IFIP Workshop Mariehamn/Aland, Finland. Pp. viii + 129. ISBN-0-08-024492-0. (Oxford, New York, Toronto, Sydney, Paris, Frankfurt: Pergamon Press, 1980.) \$22.50 f10.50.

NOVAK, M. (ed.) Software for Computer Control. Proceedings of the Second IFAC/IFIP Symposium on Software for Computer Control, Prague, Czechoslakia. Pp. xii +420. ISBN-0 08-024448-3. (Oxford, New York, Toronto, Sydney, Paris, Frankfurt: Pergamon Press, 1979.) $\$ 73.00$.

SWART/1.ANDER, E.E. jr. (ed.) (omputer Arithmetic. Benchmark Papers in Electrical Engineering and Computer Science/21. Pp xiii + 378. ISBN-0-87933-350-2. (Stroudsburg, Penn.: Dowden, Hutchinson \& Ross, Inc. 1979.) Distributed world wide by Academic Press, $\$ 45.00$.

THE ELECTRICAL RESEARCH ASSOCIATION LTD. The Engineering of Microprocessor Systems. Guidelines on System Development. Pp. xii + 175. ISBN-0-08-025435-7 Hardback ISBN-0-08-025434-9 flexi. (Oxford, New York, Toronto, Sydney, Paris, Frankfurt: Pergamon Press, 1979.) \$15.00 £7.50 Hardback \$6.00 £2.95 flexi.

\section{Applied biology}

AYRES, J.C., MUNDT, J.O. and SANDINE, E. Microbiology of Foods. Pp.708. ISBN 0 7167-1049-8 (Freeman: Oxford, 1980.) £10.80.

BRIGGS, M. H. and CORBIN, A. (eds) Advances in Steroid Biochemistry \& Pharmacology Vol. 7. Pp. 125. ISBN 0-12-037507-9 (Academic: London and New York, 1980.)\$23.00; $£ 9.80$. BROWN, K. and COOPER, S. J. (eds) Chemical Influences on Behaviour. Pp. 670. ISBN 0 12-136780-0. (Acadermic: London and New York, 1979.) £39.20; \$90.50.

BROWN, V.K. Acute Toxicity: In Theory and Practice. Pp.159. ISBN 0-471-27690-1. (John Wiley \& Sons: Chichester, 1980.) £10.00.

CAMPBEL. P. N and MARSHALL, R. D. (eds) Essays in Biochemistry, vol 15. Pp. 130 ISBN 0-12-158115-2. (Academic Press: Published for Biochemical Society, 1979.) S11.50; 84.80. CROMPTON, C. R. Additive Migration from Plastics into Food. Pp. ix + 234. ISBN-0-08022465-2. (Oxford, New York, Toronto, Sydney, Paris, Frankfurt: Pergamon Press, 1980. ) $\$ 47.00 £ 21.00$.

GALJAARD, H. Genetic Metabolic Diseases: Early Diagnosis and Prenatal Analysis. Pp. xvi +880

139.25 .

GIBSON, J. E. Thin Shells; Computing and Theory. Structures and Solid Body Mechanic (O) York: Pergamon, 1979.) \$30.00 $\$ 15.00$ hardback \$15.00 £7.50 flexi.

HARWOOD, R. F. and JAMES, M. T. Entomology in Human and Animal Health. Seventh edition. Pp. vi +548. ISBN-0-02-451600-3. (New York: Macmillan Publishing Co., Inc. Toronto: Collier Macmillan Canada, Ltd.; London: Baillière Tindall. 1980.) f18.00.

HECHT, S.M. (ed.) Bleomycin: Clinical, Biochemical, and Biological Aspects. Pp.35I. SBN 3-540-90395-X. (Springer: Berlin, Heidelberg and New York, 1979.) DM 79.00; \$34.50. JANTSCH, E. The Self-Organizing Universe Scientific and Human Implications of the Evering Paradiem of Evolution. Systems Science and World Order Library. Pp. xvii +343 iSBN-0-08-024312-6 hardback ISBN-008-024311-8 flexi. (Oxford, New York, Toronto Sydney, Paris, Frankfurt: Pergamon Press, 1979.) $\$ 44.00 £ 20.00$ hardback $\$ 15.00 £ 6.65$ flexi. JORGENSEN, S. E. Lake Management. Water Development, Supply and Manage

Pp. xii + 167. ISBN-0-08-022432-6. (Oxford, New York: Pergamon, 1980.) $\$ 36.0015 .50$. NRIA

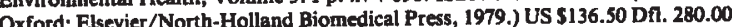

OUCHTERLONY, O. and HOLMGREN, J. (eds) Cholera and Related Diarrheas Molecular A AsBects of a Glo 0 (S. Karger: Basel, 1980.) SFr. 115.; DM 138; \$69.00.

RRY DA. and CREAMER, K (eds) Fibrous Proteins: Scientific, Industrial and Medical Aspects. Vol I. Pp. 508. ISBN 0-12-545601-4. (Academic: London and New York, 1980.) $\{19.80 ; \$ 46.00$

PARRY, D. A.D. and CREAMER, L. K. (eds) Fibrous Proteins: Scientific, Industrial and. PARRY, D. A.D. and CREAMER, $0.12-545602-2$. (Academic: London and New York, 1980.) £13.00;\$30.00.

PL IMPTON, P. (ed.) Jottings of a Harvard Botanist. Pp. 401. ISBN 76-52949 (Harvard University Press; Cambridge, Massachusetts and London, 1980). $£ 7.80$.

PLOMIN, DeFRIES a , 7167-1128-1. (Freeman: San Francisco, 1980.) \$15.00 Flexi; \$25.00 Hardback.

POLI.ARA, B., PICKERING, R.J., MEUWISSEN H.J, and PORTER, I.H. (eds) Inborn

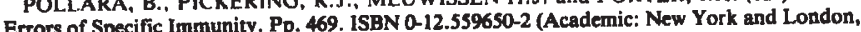
Errors of Specific $\$ 34.00$.

POLLOCK, J. R. A. (ed.) Brewing Science Vol 1. Food Science and Technology: A Series of Monographs. Pp. 604. ISBN 0-12-561001-7. (Academic: London and New York, 1979.) \&33.00; $\$ 76.00$.

RICHARDS, V. (ed.) Current Cancer Immunology. Progress in Experimental Tumour Research. Volume 25. Pp.xii +296. ISBN-3-8055-3033-1. (Basel, Munchen, Paris, London, New York, Sydney: S, Karger, 1980.) SFr. 145 DM 174 approx. US $\$ 87.00$.

SM SMIT, G. (ed.) Procecdings of the Six. Pp. xii + 468. ISBN-0-08-024918-3. (Oxford, New University of Aberdeen, Scotland.

York, Toronto, Sydney, Paris, Frank SUMMERFIELD, R. J. and A. H. BUNTING. Advances in Legume Science. Vol. 1 of the Proceedings of the International Legume Conference Kew, 31st July-4th

ISBN 0-85521-223-3 (Royal Botanic Gardens: Richmond, 1980.) £15.00. THYS, J.P., KLASTERSKY, J., and YOURASSOWSKY, E. (eds) Aerobic Gram-Ncgative Bronchopneumonias. Proceedings of the Symposium on Aerobic Gram-Negative Bronchopneumonias, Brussels, September, 1978. Pp. 183. ISBN-0.08-025533-7. York, Toronto, Sydney, Paris, Frankfurt: Pergamon Press, 1980.) $\$ 25.00$ E11.00.
UNITED NATIONS ECONOMIC COMMISSION FOR EUROPE. Problems of the Agricultural Development of Less-favoured Areas in Europe. Proceedings of a Symposium of the Committee on Agricultural Problems Economic Commission for Europe and Food and Agriculture Organisation on 22-26 May, 1978. Pp. xxi + 252. ISBN-0-08-024456-4. New York. Toronto, Sydney, Paris, Frankfurt: Pergamon Press, 1979.) $\$ 35.00$ £17.50. UNITED NATIONS ECONOMIC COMMISSION FOR EUROPE. Energy Aspects of the Forest Industries. Proceedings of a Seminar organized by the Timber Committee of the United Nations Economic Commission for Europe. Italy, 13-17 November 1978. Pp. xiii + 416. ISBNc08-025661-9. (Oxford, New York, Toronto, Sydney, Paris, Frankfurt: Pergamon Press, 1979.) 008-025661-9.

WEBB, M. (ed.) The Chemistry, Biochemistry and Biology of Cadmium. Topics in EnvironWEBB, M. (ed.) The Chemistry, Biochemistry and Biology or Cadmium. (Amsterdam and New York: mental Health Volume 2. Pp. xiii + 465. ISBN-0.444-80109-X. (Amster.
WEISS, D. W. Tumour Antigenicity and Approaches to Tumour Immunotherapy: Current Topics in Microbiology and Immunology 89. Pp. 83. ISBN 3-540-09789-9. (Springer: Berlin, Heidelberg and New York, 1980.) DM 29.00; US \$17.20.

WELCH, E. B. Ecological Effects of Waste Water: with hydrographic characteristics by $T$. Lindell. Pp. 337. ISBN 0-521-22495-0. (Cambridge University Press: Cambridge, 1980.) 115.00; Pbk £5.50.

WINEFIELD, H. R. and PEAY, M. Y. Behavioural Science in Medicine. Pr. xiii +344. ISBN-0-04-610014-8 hardback ISBN-0-04-610015-6 flexi. (London and Sydney: George Allen \& Unwin; Beaconsfield: Beaconsfield Publishers, 1980.) £10.50 hardback $\$ 5.95$ flexi.

WALKER, B. H. (ed.) Management of Semi-Arid Ecosystems. Developments in Agricultural and Managed-Forest Ecology, 7. Pp. viii + 398. ISBN-0-444-41759-1. (Amsterdam and New York: Elsevier Scientific Publishing Company, 1979.) US \$78.00 Dfl. 160.00.

ZUCKERMAN, A. J. A. Decade of Viral Hepatitis Abstracts 1969-79. Pp. 501. 0-444-801901. (Elsevier/North-Holland: Amsterdam, 1980.).

ZUCKERMAN, A. J. and HOWARD, C. R. Hepatitis Viruses of Man. Experimental Virology Series. Pp. xi +269. ISBN-0-12-78150-3. (London, New York, Toronto, Sydney, San Francisco: Academic Press, 1979.) $\mathbf{1 6 . 8 0} \$ 39.00$

\section{Psychology}

BERKOWITZ, L. (ed.) Advances in Experimental Social Psychology. Volume 12. Pp. ix + 358. ISBN-0-12-015212-6. (New York, San Francisco, London: Academic Press, 1979.) $\$ 24.00$.

GRUNEBERG, M.M. and MORRIS, P.E. (eds) Applied Problems in Memory. Pp. xiii + 289. ISBN-0-12-305150-9. (London, New York, San Francisco: Academic Press, 1979.) £12.40\$29.00.

KEEHN, J. D. (ed.) Origins of Madness. Psychopathology in Animal Life. Pp. vii +422 ISBN-0-08-023725-8. (Oxford, New York, Toronto, Sydney, Paris, Frankfurt: Pergamon Press, 1979. $\$ 40.00 £ 20.00$.

RIEBER, R. W. (ed.) Language Deveiopment and Aphasia in Children: New Essays and a translation of Kindersprache und Aphasie by Emil Fröschels. Pp.236. ISBN-0-12-588280-7. (Academic: New York and London, 1980.) \$16.00.

RUSSELL. B. Education and the Social Order. Pp. 158. ISBN-0-04-370080-2. (London, Boston, Sydney: Unwin Paperbacks, 1980.) £1.75 flexi.

SCHARFETTER, C. General Psychopathology: An Introduction. Translated by $\mathbf{H}$ Marshall. Pp. 239. ISBN 0-521-22812-3. (Cambridge University Press: Cambridge, 1980.) £20.00; Pbk £6.95.

SIMON, H. A. Models of Thought. Pp, xviii + 524. 1SBN-0-300-02347-2. (New Haven and London: Yale University Press, 1980.) £28.35.

WILDEN, A. System and Structure: Essays in Communication and Exchange. 2nd Ed. Pp. 592. ISBN 0-422-76710-7. (Tavistock London, 1980.) £14.00 Hardback, £6.95 Pbk.

\section{Sociology}

BAYLEY, L. G. Local Government Is It Manageable? A Critical and Up-to-date Assessmen of Local Government Operations with Examples and Explanations, vii + 125. ISBN-0-08024279-0. (Oxford, New York, Toronto, Sydney, Paris, Frankfurt: Pergamon Press, 1980.) $\$ 13.00 £ 5.50$.

BERTING, J, GEYER, $F$ and JURKOVICH, R. (eds) Problems in International BERTN, Methods of Rearchal Cocial Sciences. Pp. xiil +180 . ISBN-0 08-0252247-8. (Oxford, New York, Toronto, Sydney, Paris, Frankfurt: Pergamon Press, 1980.) $\$ 22.00 £ 10.00$.

CARTER, R.L. and HILL, K.Q. The Criminal's Image of the City. Pergamon Policy Studies on Crime and Justice. Pp.x+97. ISBN-0-08-024633-8. (New York, Oxford, Toronto. Sydney, Frankfurt, Paris: Pergamon Press, 1979.) 66.25 .

COP studies in Occupational stress. Pp. $x+341$. ISBN-0-471-27624-3. (Chichester, New York, Brisbane, Toronto: John Wiley \& Sons, 1980.) $£ 11.75$

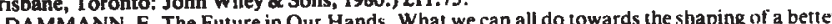
World. Pergamon International Library of Science, Technology. Engineering and Social Studies. Pp. xviii + 171. ISBN-0-08-024284-7 hardback ISBN-0-08-024283 flexi. (Oxford, New York, Toronto, Sydney, Paris, Frankfurt: Pergamon Press, 1979.) $\$ 20.00$ £9.00 Hardback $\$ 10.00$ f4.50 flexi.

GOLDSMITH, M. and KING, A. (eds) Issues of Development Towards a New Role for science and Technology; Science, Technology and Global Problems. Proceedings of an International Symposium on Science and Technology for Development, Singapore, January, 1979. Science, Technology and Global Problems Series. Pp. xxiv + 277. ISBN-0-08-024691-5. (Oxford, New York, Toronto, Sydney, Paris, Frankfurt: Pergamon Press, 1979.) $\$ 35.00$ £17.50.

GRIEVES, F. L. (ed.) Transnationalism in World Politics and Business. Pergamon Policy Studies on U. and International Business. Pp. xiii + 217. ISBN-0-08-023892-0. (New York Studies on Ur.

. The New Role of the Father in Childbirth. Pp. $x+196$. HALE, N.C. Birth of a Family. The New Role of the Father in Childbir

. the Social and Scientific Factors Involved. Pp. 473. ISBN 299-07534-6. (University of Wisconsin the Social and Scientific Factors

McAUSI.AN, P. The Ideologies of Planning Law: Urban and Regional Planning Series Vol. 22. p.282. ISBN 0-08-025198-6 (Pergamon: Oxford, 1980.) Flexi \$20.00; 28.50 Hardback $\$ 40.00 ; £ 17,00$

MORELL, J. A. Program Evaluation in Social Research. Pergamon International Library. Pp. xvi + 193. ISBN-0-08-023359-7.

Pergamon Press, 1979.) f4.50 flexi.

O'BRIEN, J.T. and MARCUS, M (eds) Crime and Justice in America. Critical issues for OBRIEN, J.T. and MARCUS, M. (eds) Crime and Jusice in Ast. ISBN-0-08-025549-3 the Future. Pergamon Policy Studies on Crime and Oxford, Toronto, Sydney, Frankfurt, Paris: Flexi ISBN-0-08-023857-2 Hardback. (New York,

Pergamon Press, 1979.) Flexi \&13.75 Hardback. PYKE, M. Long Life: Expectations for OId Age. Under 1 1 Ausp. . Dent: L.ondon, Toronto and for the Advancement of Science. Pp. 166.

SAVITCH H.V. Urban Policy and the Exterior City. Federal State and Corporate Impacts SAVIC upon Major Cites. Pergan

Oxford, Toronto, Sydney, Frankfurt, Paris: Pergamon Press, 197 . SHRADER-FRECHETTE., K. S. Nuclear Power and Public Policy: The Social and Ethica Problems of Fission Technology. Pp. 176 ISBN $90-277-1080-5$. (D. Reidel: 